\title{
Hasta-Hekim İlişkisinde Güven İletişimi: Hastaların Bakış Açısıyla Ölçmeye Yönelik Bir Ölçek Geliştirme Çalışmasıı ${ }^{\mathrm{a}}$
}

\author{
Arş. Gör. Uz. Gülsüm Şeyma KOCA ${ }^{\text {b, c }}$, Prof. Dr. Gülsün ERİGÜÇd
}

Özet

Hekim-hasta ilişkisi, sağlık bakım süreçlerinde önemli bir rol oynamaktadır. Hekime duyulan güven; artan memnuniyet, tedaviye uyum, bakımın sürekliliği de dahil olmak üzere çeşitli faydalar sağlamaktadır. Hekimin hastaya güven vermesi; ek testlere başvurma, hasta tarafından eksik bilgi verilmesinden kaynaklanan verimsizlikleri gidermekte ve etkili klinik bakım sağlamaktadır. Bu çalışmada, hekim-hasta ilişkisindeki güven konusu üç boyutta (hastanın; hekimin sağlık bakım davranışına, hekim kararlarına ve hekimin hastanın ödeme durumuna ilişkin davranışlarına duyduğu güven ile) ele alınmıştır. Çalışmanın amacı, hasta-hekim ilişkisinde güven iletişimine ilişkin bir ölçeğin geliştirilmesidir. Yapılan analizler sonucunda toplam varyansın \%56,505'ini açıklayan, 19 maddeden oluşan üç boyutlu geçerli ve güvenilir bir ölçek geliştirilmiştir.
Anahtar Kelimeler

Hasta-Hekim İlişkisi

Güven İletişimi

Ölçek Geliştirme

Geçerlik-Güvenirlik

Makale Hakkında

Geliş Tarihi: 15.02.2020

Kabul Tarihi: 10.05.2020

Doi: 10.18026/cbayarsos.689732

\section{A Scale Development Study To Measure The Trust Communication In The Patient-Physicians Relationship From A Patient Perspective}

\begin{abstract}
The physician-patient relationship plays an important role in health care processes. Trust in physicians has several benefits such as increasing satisfaction, compliance with treatment, continuity of patient care. The physician gives confidence to the patient; applying additional tests, eliminating inefficiencies caused by incomplete information disclosure by the patient and its provide effective clinical care. In this study, the issue of trust in the physician-patient relationship was discussed in three dimensions (the patient's trust in the health care behavior of the physician, physician decisions and the patient's behavior regarding the payment status). The study aims to develop a scale of trust communication in the patient-physician relationship. As a result of the analyses, a valid and reliable three-dimensional scale consisting of 19 items, which explained $56,505 \%$ of the total variance, was developed.
\end{abstract}

Keywords

Patient-Physician Relationship

Trust Communication

Scale Development

Validity-Reliability

\begin{tabular}{r} 
About Article \\
\hline Received: 15.02 .2020 \\
Accepted: 10.05 .2020 \\
Doi: $10.18026 /$ cbayarsos.689732
\end{tabular}

Doi: $10.18026 /$ cbayarsos.689732

\footnotetext{
a Bu çalışma 4. Sağlık Illetişimi Sempozyumunda bildiri olarak sunulmuştur.

b İletişim Yazarı: g.seymakoca@hacettepe.edu.tr.

c Arş. Gör. Gülsüm Şeyma KOCA, Hacettepe Üniversitesi, İktisadi ve İdari Bilimler Fakültesi, Sağlık Yönetimi Bölümü, Ankara, ORCID numarası: http://orcid.org/0000-0002-1356-3975.

d Prof. Dr. Gülsün ERIGÜÇ, Hacettepe Üniversitesi, İktisadi ve İdari Bilimler Fakültesi, Sağlık Yönetimi Bölümü, Ankara, ORCID numarası: http://orcid.org/0000-0001-5186-9345.
} 


\section{Giriş}

Güven, hasta-hekim ilişkisinin iyi bir göstergedir. Hastanın tıbbi bakım alımını daha verimli bir hale getirmektedir (Elk ve Landrine, 2012: 97). Hasta hekim arasındaki iletişimin odak noktalarından birisi de güven unsurudur (Sherwood vd., 2018). Hekim hasta arasında iyi bir iletişimin, hastalar ve hekimler için sayısız yararları olan önemli bir bakım unsuru olduğu bilinmektedir (Whitcomb, 2000). Hem hasta merkezli bakım hem de kanita dayalı uygulama modellerinin bir parçası olarak, hastanın ne istediğini ve hedeflerinin tedavi için ne olduğunu yani klinik uzmanlık ve mevcut en iyi araştırma kanıtları ile entegre hasta değerleri ve tercihlerini bilmek önemlidir (Sackett vd., 1996). Bunun aksine, sağlık bakım sürecindeki aksaklıkların önemli bir bölümü sağlık hizmeti sağlayıcısıyla olan zayıf iletişimden kaynaklanmaktadır (Lang, 2012).

Hasta merkezli iletişimin (HMI) (Patient-Centered Communication) amac1, hekimlerin, hasta değerleri, ihtiyaçları ve tercihleri ile uyumlu bakım sağlamalarına ve hastaların sağlık ve sağlık bakımı ile ilgili kararlara aktif katılımlarını sağlamalarına yardımcı olmaktır. HMİ, yüksek kaliteli sağlık bakımının, merkezi bir bileşeni olarak yaygın bir şekilde desteklenmektedir. Ancak HMÍnin, ne olduğu ve nasıl ölçüleceği açık değildir. Bu anlamda HMİ, dört iletişim alanı içerir: hastanın bakış açısı, psikososyal içerik, hasta hekim arasındaki ortaklığı ve anlayışı geliştirmek, güç ve sorumluluk paylaşımıdır (Epstein vd., 2005: 1517). İlk alan (1) Hasta bakış açısı, hastanın endişelerini, düşüncelerini, beklentilerini, ihtiyaçlarını ortaya çıkarmak ve anlamayı (2) psikososyal içerik, hastayı kendine özgü psikososyal bağlam içerisinde anlamayı, (3) hasta-hekim otaklı̆̆ı, hastaların sorunlarının çözümünde ortak bir anlayışa ulaşmayı ve hastanın değerleriyle uyumlu olan hasta tedavisine ulaşmayı, (4) güç ve sorumluluk, hastalara, istedikleri dereceye kadar seçimlerine katılarak güç ve sorumluluğu paylaşmalarına yardımcı olmayı içermektedir (Epstein vd., 2005: 1517). Şekil 1'de hasta merkezli bakımı etkileyen faktörler sunulmuştur.

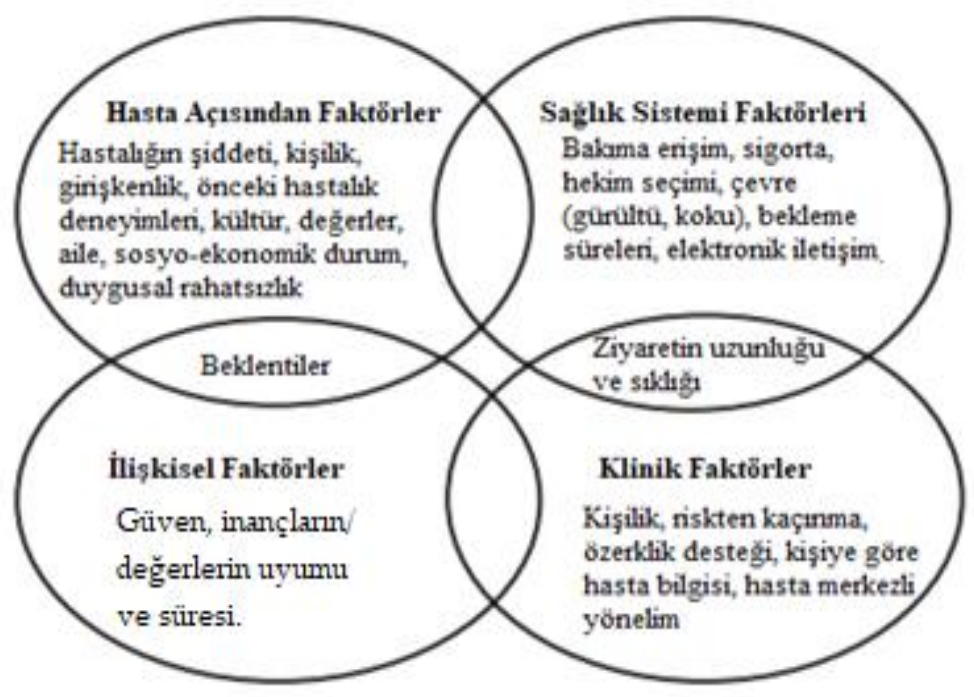

Şekil 1. Hasta merkezli bakımı etkileyen faktörler

Kaynak: Epstein et al, 2005: 1517. 
Şekil 1'de görüldüğü üzere, hasta merkezli bakımı etkileyen faktörlerden birisi de hasta-hekim arasındaki güvendir. Tıbbi bakım süreçlerinde önemli bir unsur olan hastanın tedaviye uyumu, hastanın hekimine güven duyması ile ilişkilidir (Fuertes vd., 2007: 29; Kim vd., 2004: 238). Hasta-hekim ilişkisinde güven "bir hekime, kendi uzmanlık alanında kabul edilmiş bir tıbbi bakım standardı sağlaması konusunda duyulan güven" olarak tanımlanmaktadır (Pellegrini, 2017). Güven unsuru; klinisyenler ve hastalar arasındaki etkileşimde, hastaların bakımı ile ilgili kararlarda yer alma isteklerinde oldukça önemlidir ve bu unsur, çeşitli araştırmalar ile de kanıtlanmaktadır (Song vd., 2019; Peng vd., 2020; Gulbrandsen vd., 2020).

Bu çalışmada hasta hekim ilişkisindeki güven iletişimi “Hekimin sağlık davranışına duyulan güven, hekimin kararlarına ve hekimin hastanın ödeme durumuna ilişkin davranışlarına duyulan güven" olmak üzere üç boyutta incelenmiş ve bu üç boyuta ilişkin teorik temel kavramsal çerçeve başlı̆̆ı altında verilmiştir.

\subsection{Kavramsal çerçeve}

Güven, her ne kadar hasta ve hekim arasındaki ilişkide temel bir bileşen olarak kabul edilse de Katz (1984), hekim-hasta arasında daha dürüst ve eksiksiz iletişim için her iki tarafın haklarına ve ihtiyaçlarına saygı gösteren yeni bir diyaloğu savunmaktadır. Bu diyaloğun kurulmasının temellerinden birisi de hastanın hekimin sağlık davranışına duyduğu güvendir.

Hekimin sağlık davranışına duyulan güven; hekim ve hastalar arasındaki çelişkiyi azaltabilen, hastanın uyumluluğunu ve hekimlerle hastaların uyumlu birlikteliğini artırabilen klinik tıbbın temellerindendir (Nie vd., 2017). Hastalar hekimlerine güvenlerini, hekimlerinin dürüst ve yetkin olduğu, hastaların çıkarları doğrultusunda hareket edeceklerini ve gizliliklerini koruyacakları inancına dayandırırlar (Fiscella vd., 2004; Hall vd., 2002). Hasta güveninin belirgin önemine rağmen, hangi hekim davranışının hasta ile en güçlü şekilde ilişkili olduğu hakkında nispeten az şey bilinmektedir. Hastaların güvenini artırma konusunda hekim davranışını yedi kategoride tanımlayan bir araştırmaya göre; hastanın sorunlarını iyice değerlendirmek, hastaların deneyimini anladığını göstermek, hastaya bakımını anlatmak, uygun ve etkili tedavi sağlamak, net iletişim kurmak, ortaklık kurmak, dürüstlük ve saygı göstermek hekim davranışlarını tanımlayan etmenler olarak ele alınmıştır (Thom, 2001). Burada tanımlanan davranışlar benzer şekilde de bu çalışma kapsamında hekimin sağlık bakım davranışına güven boyutunda ele alınan kavramlar ile benzeşmektedir. Bu boyut altında ele alınan kavramlar incelendiğinde, hekimlerin kendi bilgi ve gayretlerini hastalar için kullandıkları (uygun ve etkili tedaviyi sağlamak davranışıyla), hastaların ihtiyaçlarına saygılı oldukları, hastaların ihtiyaç duyduğu her türlü bakım için ne gerekiyorsa yaptıkları ve hekimin söylediklerinin doğruluğuna duyulan inanç (saygı ve dürüstlük davranışlarıyla) başlıklarıyla benzerdir. Hasta odak gruplarından elde edilen bulgularda hem algılanan hekim dürüstlügü̈nün hem de hekimin yeterliliğinin hastaların hekimlerine duydukları güvene katkıda bulunduğunu göstermektedir (Thom ve Campbell, 1997).

Hekim kararlarına güven; hastaların tıbbi bakımda tercih ettikleri rolün en önemli yordayıcısı tıp mesleğine duyulan güvendir. Hekime duyulan güvenin artması, genel olarak, hekim önerilerini takip etme ve hekimin karar verme yetkisi konusunda daha fazla güven duyulması konusundaki isteklik ile ilişkilidir. Hekime duyulan yüksek güven, tıbbi bakım istemek ve tedavi rejimlerine bağlı kalmak gibi daha aktif hasta rolleri ile de tutarlıdır (Trachtenberg vd., 2005). Tıbbi bakımda başarıyı sağlayan belki de en önemli bileşen hekimlerin yetkin olduğu, 
hastaları için uygun sorumluluk ve kontrolü aldıkları ve hastalarının refahı konusunda en yüksek önceliği verdiği konularına dair güvenine bağlıdır. Bu nedenle hekimlerin kararlarına güven literatürde son derece önemli çalışma alanlarındandır (Mechanic ve Schlesinger, 1996). Hekim-hasta ilişkisinde, bilgi asimetrisi nedeniyle hastalar hekimlerine güvenmek durumundadırlar (Mechanic ve Meyer, 2000). Hastaların hekimlere olan güveni bir hekimin hastasının çıkarları adına çalıştığı inancı hekim-hasta güvenini açılamaya yönelik en önemli etmenlerdendir (Rolfe vd., 2014). Bu çalışmada ele alınan hekim kararlarına güven boyutunda, hekimlerin izledikleri değişik tedavi seçeneklerini hastaya söyleme noktasındaki dürüstlüğü, hekimin hastanın tedavisi ile ilgili kararlara duyduğu güveni ve hastanın tedavisinde yapılan hataları hastaya aktarma konusunda hastanın hekimine duyduğu güveni ile ilgili konuları ele almaktadır. Literatürde farklı güven türlerinin hastaların çeşitli yönleri ile nasıl ilişkili olduğunun eşzamanlı olarak incelenmesi ve hastaların tıbbi bakıma katılımları hakkında görüşleri ele alınmıştır (Anderson ve Dedrick, 1990; Thom ve Champbell, 1997; Balkrishnan vd., 2003). Bu önemli bağlantıları anlamak için bu çalışma, hastaların birincil olarak hekimlerine ve tıp mesleğine duydukları güveni, tıbbi karar vermede tercih edilen rolleri ve tedavi önerilerine uyma durumlarını anlamaya yönelik olarak tasarlanmıştır.

Hekimin hastanın ödeme durumuna ilişkin davranışlarına duyulan güven boyutunda hastaların finansal ödeme durumları dikkate alınmakta ve hekimin hastanın ödeme durumu konusundaki davranışlarına karşı hastalarının hekimlerine duydukları güveni ele almaktadır. $\mathrm{Bu}$ konuya ilişkin mevcut literatürde araştırmalar mevcut olup, sağlık hizmetleri sunumundaki tüm gelişmeler hekimlerin ücretlerinin hastaların onlara güvenini etkileyebileceğini göstermektedir. Sağlık hizmeti araştırmacıları, ödeme yöntemlerinin klinik karar verme konusunda etkili olabileceğini ifade etmişlerdir (Hillmann, 1989; Hillmann, 1990; Sulmasy, 1992). Kao ve diğerleri (1998) tarafından, hastaların hekimlerine yaptıkları ödemelere göre hekime duydukları inançlarının, hekime olan güveni etkileyip etkilemediğine yönelik yapılan bir araştırmada, ödeme yöntemlerine göre kişi başına ücret alan hekimlere güvenme olasılığı daha düşük bulunmuştur. Ayrıca, hizmet başına ücret alan hekimlerin hastalarının, maaş alan hekimlerin hastalarına göre hekimlerine güvenme olasılıklarının daha yüksek olmadığı bulunmuştur. Aynı araştırmada hastalar belirli ödeme stratejileriyle ilgili endişelerini dile getirmelerine rağmen hekimlerine güvenlerini önemli bir şekilde etkilemediğini de ifade etmişlerdir.

Çok sayıda çalışma, hastanın hekime güvenini veya hastaların bakım arama konusundaki rollerini, tıbbi kararlara katılım düzeyini ve tedaviye uyumunu incelemektedir. Alan yazınında bu konu üzerine yapılan çalışmaların (Gezergün vd. (2006), Heybet vd., (2016)) olduğu görülmektir. Bu araştırmalardan Gezergün ve diğerlerinin (2006) araştırması, hastahekim arasındaki ilişkiyi hastaların bakış açısıyla değerlendirmiştir. Araştırmada literatürden derlenen sorular kullanılarak hasta-hekim ilişkisi altı boyutta incelenmiştir. Bu boyutlardan birisi de hekime duyulan güven boyutudur. Bir diğer araştırma olan Heybet ve diğerlerinin (2016) araştırması ise; hasta hekim ilişkili sağlık hizmeti sunumunun nasıl algılandığını ölçmeye çalışmış ve güven unsuru boyutlardan birisi olarak değerlendirilmiştir. Ancak bu araştırmalarda hastaların bakım arama ve tıbbi kararlara katılmaya yönelik tutum ve davranışları güven iletişimi boyutu ile incelemeye yönelik herhangi bir araç kullanılmamaktadır. Uluslararası literatürde hasta-hekim ilişkisinde güven unsurunun incelenmesine ilişkin çeşitli ölçekler bulunmaktadır (Anderson ve Dedrick., 1990; Thom vd., 1999; Bachinger vd., 2009). Bu ölçekler, güven unsurunu sağlık bakım hizmetlerindeki farklı unsurlarla; konsültasyon, empati, birinci basamak sağlık hizmetleriyle birlikte incelemiştir. Bu 
çalışma, tıbbi bakım alanında kişinin güvenini değerlendirmek için bir araç geliştirilmesi ve kişilerarası güvenin ölçüsünün, hastaların hastalık yönetimi ile ilgili davranışlarını açıklamakta yararlı olabileceği düşüncesi ile yapılmıştır. Bu çalışmanın odak noktasını, hastahekim arasındaki bu güven iletişimi oluşturmaktadır. Çalışmanın amacı, hasta-hekim ilişkisinde güven iletişimine ilişkin bir ölçek geliştirmektir. Dolayısıyla bu çalışmanın literatürde önemli bir yeri olan hasta-hekim ilişkisi ve hastanın hekimine duyduğu güvene odaklanması ve hasta-hekim ilişkisinde güven unsuruna ilişkin yapısal birtakım faktörleri ortaya koyması yönüyle literatüre fayda sağlayacağı söylenebilir. Bu çalışmadan elde edilen sonuçlar, klinik bakım süreçlerinde hekimin sağlık bakım davranışlarına, kararlarına ve hastanın ödeme durumuna ilişkin davranışlarına duyulan güvenin ölçülmesine ilişkin niceliksel bir ölçek ile ortaya konulması yönünden önemlidir. Ölçek genel anlamda hastalar üzerinde yürütülen çalışmalarda kullanılabilir olup, hasta-hekim ilişkisinde güvenin ortaya konulmasına yönelik çalışmalara katkı sağlayacağı düşünülmektedir.

\section{Yöntem}

Araştırmanın bu bölümünde araştırmanın uygulandığı çalışma grubu, ölçeğin geliştirilmesine yönelik ölçek formunun hazırlanması, verilerin analizine ilişkin bilgilere yer verilmiştir.

\subsection{Araştırmanın Amacı ve Önemi}

$\mathrm{Bu}$ çalışmada hasta-hekim ilişkisinde güven iletişimine ilişkin bir ölçek geliştirilmesi amaçlanmıştır. Bu çalışmada, teorik bir yapının test edildiği bir yapıya ihtiyaç duyulmuştur. Dolayısıyla, bu çalışma kapsamında geliştirilen ölçeğin hasta-hekim ilişkisindeki güven unsurunun yapısal olarak ortaya koyma açısından önem taşıdığı ve bu yönde literatüre katkı sağlayabileceği söylenebilir.

\subsection{Araştırmanın Çalışma Grubu}

Araştırmanın çalışma grubu kesitsel türde belirlenmiştir. Bu kapsamda, Ankara'da bir Eğitim Araştırma Hastanesine tedavi görmek amaciyla başvuran toplam 283 hasta araştırmanın çalışma grubunu oluşturmaktadır. Araştırmada 15 yaşından küçük olan, okuryazar olmayan, ağır işitme problemi olan hastalar çalışma kapsamı dişında tutulmuştur ve bu gruptaki hastalara anket uygulanmamıştır.

\subsection{Araştırmanın İşlem Basamakları}

$\mathrm{Bu}$ çalışmada hasta-hekim arasındaki güven ilişkisinde bir unsur olan güven iletişiminin belirlenmesine yönelik bir ölçeğin geliştirilmesi amaçlanmıştır. Bu amaçla, ilgili alan yazını incelenmiştir. Yılmaz (2005)'in hasta-hekim arasındaki güven iletişimini incelediği tez araştırmasında faydalandığı ilgili literatürü baz alarak son hali verilen anket form temel alınmıştır. Bu anket uygulanarak yapılan analizler sonucunda; araştırmada, hekimin sağlık davranışına duyulan güven, hekimin kararlarına güven ve hekimin hastanın ödeme durumuna ilişkin davranışlarına duyulan güven kavramlarının ele alındığı üç boyut oluşturulmuştur. Bu çalışma kapsamında ele alınan alt boyutlardaki maddeler literatürde yapılan çeşitli araştırmalarda da benzer şekillerde ele alınmıştır (Caterinicchio, 1979; Crawshaw, 1995; Thom ve Champbell, 1997; Thom vd., 1999; Thom, 2000; Thom, 2001; Thom vd., 2002; Parchman ve Burge, 2004; Weng, 2008; Thom vd., 2011; Martin vd., 2013; Pellegrini, 2017). Bu araştırmalarda ele alınan hasta hekim ilişkisinde güven iletişimi ilişkide hekimin 
teknik yeterliliği (sorunları iyice değerlendirme, uygun ve etkili tedavi sağlama) alt kategorisi, bu çalışmadaki hekimin sağlık bakım davranışlarına güven boyutundaki maddeler ile benzerdir. Ek olarak, yapısal/kişisel faktörler alt kategorisi (hastanın kişisel deneyimini anlama, bakımına özen gösterme, açı ve eksiksiz iletişim/aktif dinleme, dürüstlük/hastaya sayg1 gösterme gibi faktörler) hekim kararlarına güven boyutundaki soru maddeleri ile örtüşmektedir. Benzer şekilde hekimlerin birincil bakımda temel aldıkları tutuma ilişkin araştırmalarda yer alan "güven" kategorisi, bu araştırmada hekimin hastalara tedavi seçeneklerini söyleme konusundaki dürüstlügüünün ele alındığı sorular ile benzerdir. Bu kapsamda bu araştırma ele alınan maddeler alan yazınını ile uyumlu olduğu söylenebilir. Ayrıca, çalışma kapsamında ele alınan soruların incelenen konunun tüm alt konularını içerip içermediğine, içeriyorsa kapsam geçerliliğinin ortaya konulması amacıyla uzman görüşüne başvurulması yoluna gidilmiştir. Kapsam geçerliğinin değerlendirilmesinde "İletişim" alanında uzman 3 öğretim üyesince, maddeler üçlü derecelendirme yöntemiyle değerlendirilmiş ve Kapsam geçerlik oranı hesaplanmıştır. Uzman görüşü sonrası kapsam geçerlik oranı $0,67^{\prime}$ den düşük bir maddenin bulunmaması sonucu sorular madde havuzunda bırakılmıştır ve 22 maddelik soru formu, ölçülmek istenilen yapıyı ölçüp ölçmediğinin belirlenmesi amacıyla test edilmiştir. Ölçeğin geçerliliği, yapı geçerliliği ile ortaya konulmuş olup, ayrışma-birleşim geçerliliğine ilişkin sonuçlar çıkarılmış ortalama varyans (average variance extracted, AVE) ve birleşik güvenirlik (composite reliability, CR) değerleri ile birlikte verilmiştir. Faktör analizi sonucu elde edilen yapı Doğrulayıcı Faktör Analizi (DFA) ile test edilmiştir. Ölçeğin güvenilirliği, Split-Half Reliability metodu kullanılarak ortaya konulmuştur. Yapılan analizler neticesinde varyansın \%56,505'ini açıklayan bu ölçek geçerli ve güvenilir bulunmuştur.

\section{Bulgular}

Araştırmanın bulguları, geçerlik ve güvenilirlik sonuçlarına ilişkin analizler ve tablolarla bu bölüm altında incelenmiştir.

\section{1. Ölçeğin Geçerlik Analizi}

Ölçeğin geçerlik analizleri, kapsam geçerlik ve yapı geçerliliği ile ortaya konulmuştur. Kapsam geçerliğine ilişkin analizler neticesinde kapsam geçerlik indeksi hesaplanmış ve istatistiksel analizler sonucunda madde havuzunda kalan maddelerin geçerlik oranı 0,795 olarak elde edilmiştir. Buna göre ölçekteki maddeler ölçülmek istenen konuları içerdiği görülmüştür. Kapsam geçerlik analizi sonrası yapı geçerliğinin ortaya konulması amacıyla öncelikle ölçekteki maddelerin ölçeğe katkısı madde analizi ile incelenmiştir. Madde analizi ölçekte yer alan maddelerin ölçeğe katkısının incelenmesi amacıyla yapılan bir analiz olup değerlendirmelerde maddelere ilişkin ortalama ve standart sapmalar incelenmektedir. Ayrıca madde silindiğinde güvenilirlik katsayısının incelenmesi, çoklu açıklayıcılık katsayısı ve altüst \%27'lik gruplara ilişkin madde ortalamalarının karşılaştırılması ile ölçekteki maddelere karar verilmektedir. 


\subsubsection{Maddelere İlişkin Ortalama ve Standart Sapmaların İncelenmesi}

Maddelere ilişkin ortalama ve standart sapma değerleri $(n=283)$ Tablo 1'de gösterilmiştir.

Tablo1. Madde İstatistikleri

\begin{tabular}{|c|c|c|c|}
\hline Ölçek Maddeleri & Ortalama & Standart Sapma & n \\
\hline gi1 & 3,41 & 1,00 & 283 \\
\hline gi2 & 3,36 & 0,88 & 283 \\
\hline gi3 & 3,29 & 0,97 & 283 \\
\hline gi4 & 3,46 & 0,88 & 283 \\
\hline gi5 & 3,34 & 1,03 & 283 \\
\hline gi6 & 3,40 & 0,99 & 283 \\
\hline gi7 & 3,77 & 0,90 & 283 \\
\hline gi8 & 3,55 & 0,89 & 283 \\
\hline gi9 & 2,77 & 1,05 & 283 \\
\hline gi10 & 3,38 & 1,00 & 283 \\
\hline gi11 & 3,73 & 0,86 & 283 \\
\hline gi12 & 3,48 & 0,84 & 283 \\
\hline gi13 & 2,90 & 1,10 & 283 \\
\hline gi14 & 2,92 & 1,04 & 283 \\
\hline gi15 & 3,01 & 1,03 & 283 \\
\hline gi16 & 3,25 & 1,01 & 283 \\
\hline gi17 & 3,00 & 1,05 & 283 \\
\hline gi18 & 3,86 & 0,79 & 283 \\
\hline gi19 & 3,16 & 1,00 & 283 \\
\hline gi20 & 3,32 & 1,02 & 283 \\
\hline gi21 & 3,13 & 0,98 & 283 \\
\hline gi22 & 3,50 & 0,98 & 283 \\
\hline
\end{tabular}

Madde istatistiklerinde, maddelere ilişkin ortalamaların birbirine benzer ve maddelere ilişkin dağılımın tek tepeli olması ve normal dağılım göstermesi istemektedir. Tablo 1 incelendiğinde maddelere ilişkin ortalamaların 3,77 ile 2,77 arasında değiştiği görülmektedir. Ortalama ve standart sapma değerlerinin birbirlerine benzer olduğu 9, 13 ve 14 . maddelerin diğer maddelere göre ortalamasının daha düşük olmasına rağmen diğer ölçek maddelerinin ortalamalarına yakın bir dağılım göstermiştir. Bu durum, araştırmaya katılan bireylerin ölçülmeye çalışılan özellik konusunda benzer fikirlerde olduğu şeklinde ifade edilebilir. 
Maddelere ilişkin ortalama ve standart sapma değerleri bir fikir vermekle birlikte, tek başına yeterli değildir. Dolayısıyla maddelere ilişkin korelasyon katsayılarına da bakmak gerekmektedir. Ölçek maddelerinin standart sapma değerleri incelendiğinde tüm maddeler için korelasyon değerleri incelenebilmektedir.

Tablo 2'de maddeler arası korelasyon değerleri verilmektedir. Korelasyon matrisi incelendiğinde, korelasyon değerlerinin 0,176 ile 0,683 arasında bir değişim göstermektedir. Ölçekte negatif değer alan bir korelasyon katsayısı yoktur. Ancak, korelasyon matrisindeki bazı maddelerin $(1,2,5,7,9,13$ ve 20) 0,25 'in altında kaldığ 1 görülmektedir. Ortalama standart sapma değeri düşük olan 9, 13 ve 14. maddelerin ise korelasyon değerlerinin orta düzeyde olduğu ve ölçekten çıkarılmamasını gerektirmediği söylenebilir.

Tablo 2. Maddelere İlişkin Korelasyon Matrisi

\begin{tabular}{|c|c|c|c|c|c|c|c|c|c|c|c|c|c|c|c|c|c|c|c|c|c|c|}
\hline & gi1 & gi2 & gi3 & gi4 & gi5 & gi6 & gi7 & gi8 & gi9 & gi10 & gi11 & gi12 & gi13 & gi14 & gi15 & gi16 & gi17 & gi18 & gi19 & gi20 & gi21 & gi22 \\
\hline gi1 & 1,000 & & & & & & & & & & & & & & & & & & & & & \\
\hline gi2 & 421 & 1,000 & & & & & & & & & & & & & & & & & & & & \\
\hline gi3 & 493 & 494 & 1,000 & & & & & & & & & & & & & & & & & & & \\
\hline gi4 & 450 & 492 & 468 & 1,000 & & & & & & & & & & & & & & & & & & \\
\hline gi5 & 293 & 329 & 383 & 323 & 1,000 & & & & & & & & & & & & & & & & & \\
\hline gi6 & 337 & 322 & 350 & 353 & ,366 & 1,000 & & & & & & & & & & & & & & & & \\
\hline gi7 & 244 & 252 & 275 & 289 & ,306 & 405 & 1,000 & & & & & & & & & & & & & & & \\
\hline gi8 & 479 & 374 & 482 & 492 & 410 & 405 & 393 & 1,000 & & & & & & & & & & & & & & \\
\hline gi9 & 323 & 303 & 437 & 343 & 360 & 356 & 244 &, 382 & 1,000 & & & & & & & & & & & & & \\
\hline gi10 & 380 & 383 & 492 & 435 & 366 & 470 & 286 & 451 & 511 & 1,000 & & & & & & & & & & & & \\
\hline gi 11 & 439 & 405 & 468 & 378 & ,324 & 413 & 324 & 440 & 341 & 470 & 1,000 & & & & & & & & & & & \\
\hline gi 12 & 448 & 415 & 440 & 454 & ,367 & 369 & 338 & 453 & 308 & 475 & 664 & 1,000 & & & & & & & & & & \\
\hline gi 13 & ,391 & 333 & 392 & 412 & ,339 & 410 & 339 &, 374 & 374 & 419 & 381 &, 510 & 1,000 & & & & & & & & & \\
\hline gi 14 & 375 & 371 & 433 & 401 & ,309 & 435 & 259 & 378 & 412 & 459 & 424 & 475 & 519 & 1,000 & & & & & & & & \\
\hline gi 15 & 310 & 338 & 353 & 320 & ,393 & 418 & 340 & ,304 & 437 & 436 & 357 & ,355 & 426 & 468 & 1,000 & & & & & & & \\
\hline gi 16 & 432 & 387 & 431 & 366 & ,388 & 428 & 372 & 485 & 488 & 532 & 447 & 460 & 465 & 531 & 569 & 1,000 & & & & & & \\
\hline gi 17 & 377 & 336 & 434 & 408 & ,291 & 466 & 289 & 405 & 400 & 466 & 397 & 404 &, 536 & 683 & 467 & 612 & 1,000 & & & & & \\
\hline gi 18 & 336 & 371 & 375 & 410 & 257 & ,365 & 407 & 384 & 181 & 294 & 456 & 455 & 328 & 300 & 365 & 385 & 338 & 1,000 & & & & \\
\hline gi 19 & 310 & 249 & 314 & 282 &, 340 &, 239 & 226 & 299 & 493 & 366 & 315 &, 334 & 276 & 350 & 479 & 477 & 408 & 324 & 1,000 & & & \\
\hline gi 20 & 237 & 269 & 281 & 256 & 176 & 272 & ,204 & ,307 & 413 & 383 & 301 & 327 & 224 & 254 & 306 & 344 & 264 & 380 & 509 & 1,000 & & \\
\hline gi 21 & 330 & 350 & 435 & 367 & ,221 & 432 & 235 & 416 & 397 & 459 & 459 & 425 & 408 & 471 & 396 & 478 & 500 & 395 & 386 & 421 & 1,000 & \\
\hline gi 22 & 415 & 343 & 509 & 382 & 297 & 373 & 382 & 484 & 385 & 457 & 525 & 439 & 431 & 400 & 372 & 468 & 416 & 401 & 345 & 387 & 455 & 1,000 \\
\hline
\end{tabular}

Tablo 3'te madde bütün istatistikleri verilmiştir. Madde silindiğinde ortalamaların büyük değişiklikler göstermemesi beklenmektedir. Tablo 3'te madde silindiğinde ortalamalarda önemli değişiklikler olmadığı görülmektedir. Ölçeğin toplam güvenilirlik katsayısı 0,932 olarak hesaplanmıştır. Buna göre, madde silindiğinde korelasyon katsayılarının yer aldığ sütun incelendiğinde, maddelerin bu değere yakın değerler aldığı dolayısıyla da ölçekten 
çıkarılmasına gerek kalmadığı söylenebilir. Ayrıca, çoklu açıklayıcılık katsayısı olan $\mathrm{R}^{2}$ değerlerine göre incelendiğinde 2,5 ve 7 . maddelerin $R^{2}$ değerlerinin düşük olduğu ve maddelerin korelasyon katsayılarının daha önce yapılan maddelere ilişkin korelasyon katsayısında da düşük değerler aldığ işaret etmekle birlikte, diğer istatistikler ile incelendiğinde ölçeğin güvenilirliğinin artması yönünde bir katkı sağlamayacağı ve ölçekte yer almasının uygun olduğu ifade edilebilir.

Söz konusu maddelerin açılayıcı faktör analizi ile de maddelerin incelenmesi gerekmektedir.

Tablo 3. Madde-Bütün İstatistikleri

\begin{tabular}{|c|c|c|c|c|c|}
\hline $\begin{array}{c}\text { Ölçek } \\
\text { Maddeleri }\end{array}$ & $\begin{array}{c}\text { Madde } \\
\text { Silindiğinde } \\
\text { Bütün } \\
\text { Ortalaması }\end{array}$ & $\begin{array}{c}\text { Madde } \\
\text { Silindiğinde } \\
\text { Bütün Varyansı }\end{array}$ & $\begin{array}{c}\text { Madde-Bütün } \\
\text { Korelasyon } \\
\text { Katsayısı }\end{array}$ & $\mathbf{R}^{2}$ & $\begin{array}{c}\text { Madde } \\
\text { Silindiğinde } \\
\text { Cronbach's } \\
\text { Alpha }\end{array}$ \\
\hline gi1 & 69,604 & 172,517 & 0,573 & 0,405 & 0,930 \\
\hline gi2 & 69,657 & 174,949 & 0,552 & 0,387 & 0,930 \\
\hline gi3 & 69,728 & 171,234 & 0,645 & 0,497 & 0,928 \\
\hline gi4 & 69,558 & 173,978 & 0,593 & 0,443 & 0,929 \\
\hline gi5 & 69,678 & 173,914 & 0,501 & 0,342 & 0,931 \\
\hline gi6 & 69,625 & 172,136 & 0,590 & 0,423 & 0,929 \\
\hline gi7 & 69,247 & 176,634 & 0,466 & 0,324 & 0,931 \\
\hline gi8 & 69,466 & 172,938 & 0,634 & 0,480 & 0,929 \\
\hline gi9 & 70,251 & 171,394 & 0,588 & 0,468 & 0,929 \\
\hline gi10 & 69,632 & 170,035 & 0,669 & 0,498 & 0,928 \\
\hline gi11 & 69,286 & 173,361 & 0,642 & 0,557 & 0,929 \\
\hline gi12 & 69,537 & 173,292 & 0,657 & 0,580 & 0,928 \\
\hline gi13 & 70,116 & 169,791 & 0,614 & 0,463 & 0,929 \\
\hline gi14 & 70,092 & 169,956 & 0,649 & 0,554 & 0,928 \\
\hline
\end{tabular}


Tablo 3. Madde-Bütün İstatistikleri (Tablo 3'ün Devamı)

\begin{tabular}{|c|c|c|c|c|c|}
\hline $\begin{array}{c}\text { Ölçek } \\
\text { Maddeleri }\end{array}$ & $\begin{array}{c}\text { Madde } \\
\text { Silindiğinde } \\
\text { Bütün } \\
\text { Ortalaması }\end{array}$ & $\begin{array}{c}\text { Madde } \\
\text { Silindiğinde } \\
\text { Bütün Varyansı }\end{array}$ & $\begin{array}{c}\text { Madde-Bütün } \\
\text { Korelasyon } \\
\text { Katsayısı }\end{array}$ & $\mathbf{R}^{2}$ & $\begin{array}{c}\text { Madde } \\
\text { Silindiğinde } \\
\text { Cronbach's } \\
\text { Alpha }\end{array}$ \\
\hline gi15 & 70,003 & 171,053 & 0,611 & 0,468 & 0,929 \\
\hline gi16 & 69,760 & 168,743 & 0,714 & 0,580 & 0,927 \\
\hline gi17 & 70,018 & 169,287 & 0,665 & 0,605 & 0,928 \\
\hline gi18 & 69,152 & 176,512 & 0,548 & 0,430 & 0,930 \\
\hline gi19 & 69,859 & 173,313 & 0,542 & 0,471 & 0,930 \\
\hline gi20 & 69,696 & 174,716 & 0,476 & 0,409 & 0,931 \\
\hline gi21 & 69,890 & 171,637 & 0,625 & 0,455 & 0,929 \\
\hline gi22 & 69,512 & 171,229 & 0,640 & 0,471 & 0,928 \\
\hline
\end{tabular}

Ölçeğin yapı geçerliliğinin ortaya konulması amacıyla Açıklayıcı Faktör Analizi (AFA) yapılmıştır. Yapılan açıklayıcı faktör analizi sonucunda tüm maddelerin yer aldığı ilk analizde toplam varyansın \%52,928' inin açıklandı̆̆ 1 bir ölçek elde edilmiştir. Ayrıca, "Hekimlerin tıbbi kararları genellikle doğrudur", "Bir hekim asla hastası için yanlış ilaç vermez" ve "Hekimler, hastaların hassas tıbbi bilgilerini konu ile ilgisi olmayan kimseler ile paylaşmazlar" ifadeleri diğer madde boyutlarda da birbirine yakın yüklenmiştir. Diğer istatistikler ile de incelendiğinde bu maddelerin $\mathrm{R}^{2}$ değerleri diğer maddelere göre düşük ve bazı maddelerle korelasyon değerleri 0,25 'in altında kalmıştır. Tüm bu istatistiksel değerlendirmeler ve maddelerin faktör yükleri göz önüne alınarak bu maddelerin ölçekten çıkarılmasına karar verilmiştir. Bu maddeler analizden çıkarılarak tekrar açıklayıcı faktör analizi yapılmıştır. Buna göre varyansın \%56,505'inin açıklandığı, 3 boyutlu bir yapı elde edilmiştir. Örneklem büyüklügüünün uygunluğuna yönelik yapılan $\mathrm{KMO}$ testi sonucunda $\mathrm{KMO}$ değerinin 0,938 olması bu veriler için faktör analizinin uygulanabileceğini göstermekle birlikte, Barlett Küresellik testi anlamlıdır. Yani değişkenler arasında ilişki bulunmaktadır. Buna göre, yapılan açıklayıcı faktör analizi sonucunda 19 maddeden ve 3 boyuttan oluşan bir ölçek geliştirilmiştir. Açıklayıcı Faktör Analizi sonucu elde edilen sonuçlar Tablo 4'te verilmektedir. 
Tablo 4. Hasta-Hekim İletişimde Güven İletişimi Ölçeği Faktör Analizi Sonuçları

\begin{tabular}{|c|c|c|c|c|c|c|}
\hline $\begin{array}{l}\text { Hasta-Hekim İletişiminde Güven } \\
\text { İletişimi Ölçeği Maddeleri/ Boyutları }\end{array}$ & $\begin{array}{l}\text { Faktör } \\
\text { Yükü }\end{array}$ & Varyans & $\begin{array}{l}\text { Toplam } \\
\text { Varyans }\end{array}$ & $\begin{array}{c}\text { Cronbach's } \\
\text { Alfa }\end{array}$ & AVE & CR \\
\hline \multicolumn{7}{|c|}{ 1. Boyut: Hekimin Sağlık Bakım Davranışlarına Güven } \\
\hline G1 & 0,635 & \multirow{9}{*}{23,194} & \multirow{9}{*}{23,194} & \multirow{9}{*}{0,878} & \multirow{9}{*}{0,392} & \multirow{9}{*}{0,851} \\
\hline G3 & 0,614 & & & & & \\
\hline G4 & 0,626 & & & & & \\
\hline G8 & 0,655 & & & & & \\
\hline G10 & 0,423 & & & & & \\
\hline G11 & 0,710 & & & & & \\
\hline G12 & 0,701 & & & & & \\
\hline G18 & 0,632 & & & & & \\
\hline G22 & 0,598 & & & & & \\
\hline \multicolumn{7}{|l|}{ 2. Boyut: Hekimin Kararlarına Güven } \\
\hline G6 & 0,521 & \multirow{6}{*}{20,098} & \multirow{6}{*}{43,292} & \multirow{6}{*}{0,853} & \multirow{6}{*}{0,403} & \multirow{6}{*}{0,795} \\
\hline G13 & 0,640 & & & & & \\
\hline G14 & 0,764 & & & & & \\
\hline G16 & 0,620 & & & & & \\
\hline G17 & 0,781 & & & & & \\
\hline G21 & 0,403 & & & & & \\
\hline \multicolumn{7}{|c|}{ 3. Boyut: Hekimin Hastanın Ödeme Durumuna İlişkin Davranışlarına Güven } \\
\hline G9 & 0,567 & \multirow{4}{*}{13,213} & \multirow{4}{*}{56,505} & \multirow{4}{*}{0,758} & \multirow{4}{*}{0,430} & \multirow{4}{*}{0,741} \\
\hline G15 & 0,428 & & & & & \\
\hline G19 & 0,765 & & & & & \\
\hline G20 & 0,796 & & & & & \\
\hline
\end{tabular}

Ölçeğin ayrışma-birleşim geçerliliğine ilişkin sonuçlar incelendiğinde ölçekteki yapılar arası korelasyon AVE ve CR değerleri verilmektedir (Bakınız Tablo 4).

Literatürde, AVE değerlerinin 0,50'in üzerinde olmasının ve CR değerlerin de 0,70'in üstünde olmasının yapı geçerliliğine göre iyi bir uyum göstergesi olduğu belirtilmektedir. Hair ve diğerleri (2014: 619) çıkartılmış varyans değerlerinin (AVE) 0,50'nin üzerinde olmasının ve 
birleşik güvenilirlik değerlerinin (CR) 0,70'in üzerinde olmasının ölçülmek istenen yapının geçerliliğine ilişkin iyi bir değeri ortaya koyduğunu; 0,60 ile 0,70 aralığındaki değerlerin ise kabul edilebilir olduğunu yani, ölçümlerin aynı yapıyı temsil ettiğini belirtmiştir. Bu çalışmada AVE değerleri kabul edilenden biraz düşük olmakla birlikte, CR değerleri kabul edilir düzeylerdedir. Ayrıca, Hatcher (1994)'e göre yapı güvenilirliği kabul edilebilir bir düzeyde ise düşük AVE değerlerinin kabul edilebilir olduğunu belirtmiştir. Bu çalışmada da yapı güvenilirliği kabul edilebilir değerlerde olup, AVE değerini 0,40-0,50 arasında olmasının kabul eden çeşitli araştırmalarında mevcuttur (Urfa vd., 2019; Huang vd., 2013; Yıldız vd., 2016). Buna göre ölçek ölçülmek istenen yapıyı ölçmekte yeterli olduğu söylenebilir.

Ölçeğe ilişkin faktör analizi sonuçları incelendiğinde;

-Birinci faktör toplam varyansın \%23,194'ünü açıklamaktadır. Boyuttaki maddeler hastaların ihtiyaçları ve sağlık bakım ile ilgili gayretleri vs. ile ilgili olması nedeniyle bu boyut, hekimlerin sağlık bakım davranışlarına güven olarak adlandırılmıştır. Bu boyuttaki maddeler $1,3,4,8,10,12$, 18 ve 22 . Maddelerden oluşmakta olup, birinci boyuttun güvenilirliği 0,878 olarak elde edilmiştir.

-İkinci faktör varyansın \%20,098'ini, toplam varyansın \%43,292'sini açıklamaktadır. Bu boyutta yer alan ifadeler hekim kararları ve hastaların bu kararlarına duydukları güvene ilişkindir. İkinci boyut, hekim kararlarına güven olarak adlandırılmıştır. İkinci boyutun güvenilirliği 0,853 olarak bulunmuştur.

-Üçüncü faktör varyansın \%13,213'ünü, toplam varyansın \%56,505'ini açıklamaktadır. Üçüncü boyuttaki ifadeler hastaların para ödeme ve muayene harcamaları konularına ilişkin davranışları ile ilgilidir. Söz konusu boyut hekimin hastanın ödeme durumuna dair davranışlarına ilişkin güven olarak adlandırılmıştır.

Yapılan Açıklayıcı Faktör Analizi (AFA) sonucunda, varyansın \%56,505'ini açılayan, 19 maddeden oluşan ve 3 alt boyutu bulunan hasta-hekim ilişkisinde güven iletişimi üzerine ilişkin bir ölçek geliştirilmiştir.

Açıklayıcı Faktör Analizi sonucunda elde edilen yapı Doğrulayıcı Faktör Analizi (DFA) ile test edildiğinde, elde edilen bulgular Şekil 1'de gösterilmektedir. Buna göre, açıklayıcı faktör analizi ile belirlenen yapının kuramsal olarak faktör yapısına uygunluğu DFA kullanılarak test edilmiştir. Çok değişkenli normal dağılım metodu, En Çok Olabilirlik (Maximum Likelihood) Method'u kullanılarak yapılan analiz sonucunda maddelere ilişkin $t$ değerleri incelenmiştir. Yapısal Eşitlik Modeli çerçevesinde yapılan analizlerde anlamlı olmayan $t$ değerinin bulunmadığı, dolayısıyla modelden çıkarılması gereken bir maddenin bulunmadığı tespit edilmiştir. Yapılan Yapısal Eşitlik Modeline göre beklenen kovaryans değerleri ile gözlenen kovaryans değerleri arasındaki farkın anlamlı olmaması istenmektedir. Bu çalışmada elde edilen değer anlamlı bulunmuştur. Bu durumun faktör analizindeki örneklemin büyük olmasından kaynaklanabildiği düşünülmektedir. Ayrıca X²/sd oranı 2,135 olarak elde edilmiştir. Bu durum ölçeğin kabul edilebilir bir uyum gösterdiğini ortaya koymaktadır. Uyum indis değerleri, RMSEA $=0.063, \mathrm{CFI}=0.98, \mathrm{GFI}=0.89$ ve AGFI $=0.86$ olarak elde edilmiştir. Bu kapsamda, DFA analizine göre elde edilen modelin doğrulandığ 1 ifade edilebilir.

Şekil 2'de Hasta-Hekim İlişkisinde Güven İletişimi Ölçeği'ne ilişkin Doğrulayıcı Faktör Analizi Sonuçları yer almaktadır. 


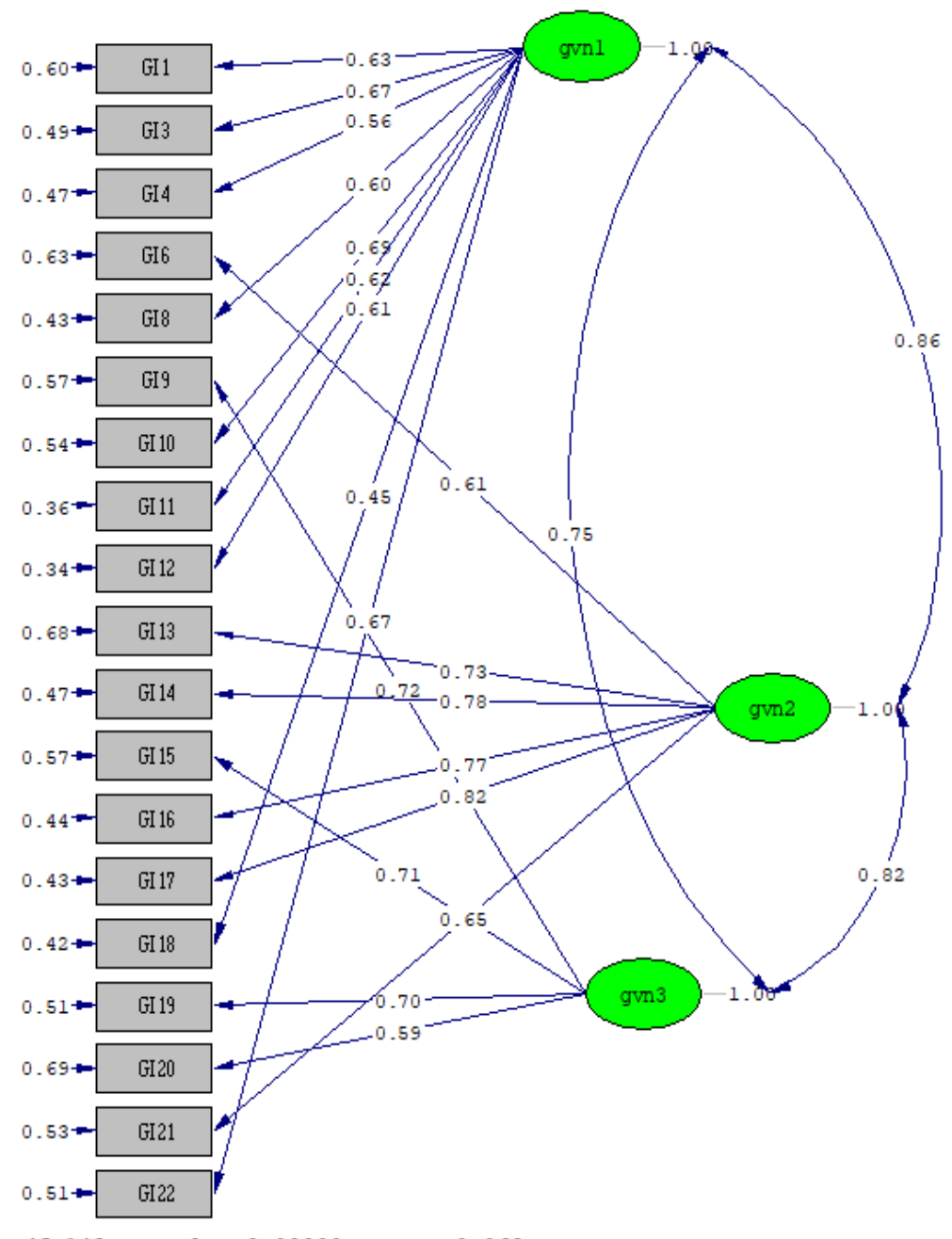

Chi-Square=318.15, df=149, P-value=0.00000, RMSEA $=0.063$

Şekil 2. Doğrulayıcı Faktör Analizi Sonuçları: Hasta-Hekim İlişkisinde Güven İletişimi Ölçeği 
Tablo 5'te, yapisal eşitlik modeli kapsamında elde edilen Uyum İndis Değerleri yer almaktadır.

Tablo 5. Modele İlişkin Uyum İndis Değerleri

\begin{tabular}{|c|c|c|}
\hline Uyum İndis Değerleri & Model & Uyum \\
\hline $\mathrm{X}^{2} / \mathrm{sd}$ & $318,15 / 149=2,135$ & Kabul Edilir Uyum \\
\hline RMSEA & 0,063 & İyi Uyum \\
\hline CFI & 0,98 & İyi Uyum \\
\hline GFI & 0,89 & İyi Uyum \\
\hline AGFI & 0,86 & İyi Uyum \\
\hline
\end{tabular}

Açıklayıcı Faktör Analizi sonucunda elde edilen yapı Doğrulayıcı Faktör Analizi ile de doğrulanmıştır.

\section{Sonuç}

Hasta-hekim arasındaki ilişki tıbbi bakım ve iyileşmenin gerçekleşmesini sağlayarak tıbbi bakım sürecinde önemli bir rol oynamaktadır. Bu çalışmada, hasta-hekim ilişkisinde güven iletişimi üzerine bilgiler sunulmaktadır. Hasta-hekim arasındaki güven oluşumu, hastanın tedaviye uyumunu arttıran ve tıbbi tedavi üzerinde olumlu etkisi olan bir unsurdur. Dolayısıyla hekim-hasta arasındaki güveni teşvik etmek, iyileştirmek ve arttırmak açısından hastaların hekimlerine duydukları güven iletişiminin incelenmesine ilişkin teorik ve pratik çıkarımlara ilişkin bilgiler açısından bu ölçek önemli bilgiler sunmaktadır.

Araştırma, hekim-hasta etkileşiminde güveni incelemek açısından literatüre katkıda bulunmaktadır. Çalışma sonucunda üç alt boyutu bulunan 19 maddeden oluşan bir ölçek geliştirilmiştir. Boyutlar; hekimin sağlık bakım davranışına güven, hekimin kararlarına güven ve hekimin hastanın ödeme durumuna ilişkin davranışlarına güven olarak isimlendirilmiştir. Çalışmada öncelikle kapsam geçerliliği ortaya konulmuştur. Bu kapsamda madde havuzuna alınan maddeler uzman görüşüne sunulmuş ve kapsam geçerlilik analizleri yapılmıştır. Kapsam geçerliliği ortaya konulduktan sonra boyutlara ilişkin yapının belirlenmesi amacıyla öncelikle Madde Analizi yapılmıştır. Maddelerin korelasyon matrisleri ve Madde-Bütün İstatistikleri ortaya konulmuştur ve madde analizi sonucu maddelere ilişkin elde edilen sonuçlar Açıklayıcı Faktör Analizi ile de incelenmiştir ve ilk yapılan AFA analizi sonucu üç madde ölçekten çıkarılmıştır. Böylelikle tekrar yapılan analiz sonucunda üç alt boyutlu bir yapı elde edilmiş ve boyutların güvenilirliği Cronbach's Alpha değeri ile ortaya konulmuştur. Ayrıca Split-Half katsayısı ile toplam güvenilirliği incelenmiştir. Ölçek yüksek düzeyde güvenilirliğe sahiptir.

Bu çalışmada ortaya konulan ölçek ile hem hekimin hastaya olan güvenini hem de hekime olan hasta güvenini ölçebilmek, klinisyen-hasta ilişkisinde karşılıklı güvenin, hasta-hekim etkileşiminin kalitesini korumaya ve iyileştirmeye yardımcı olabilecek rolünün araştırılmasını kolaylaştıracaktır. Gelecek araştırmalar için hekimlere duyulan düşük güvenin sağlık sonuçlarına ve hekim davranışlarında hastaları etkileyen olumsuz durumların sağlık hizmeti kalitesine, performansına, hasta memnuniyetine etkisi araştırılabilir. Bir başka araştırma alanı 
ise güvenin bakım süreçleri ile ilişkilendirilmesidir. Bakımın sürekliliği, hastaların tedaviye uyumları ve bakım modelleri karşılıklı güveni nasıl etkileyeceğine dair konuların ele alınması araştırmacılara önerilmekte ve ileride bu konu üzerine çalışmak isteyen araştırmacılar için geliştirilen ölçeğin faydalı olabileceği düşünülmektedir.

\section{Teşekkür ve Bilgilendirme}

$\mathrm{Bu}$ araştırmanın gerçekleştirilmesinde araştırmanın yapıldığı hastaneye, çalışanlarına ve araştırmaya katılan tüm katılımcılara teşekkür ederiz. Ayrıca, bu araştırmada yararlanılan anket formun temel alındığı Yılmaz (2005)'e de teşekkürü bir borç biliriz.

\section{Kaynaklar}

Anderson, L. A., \& Dedrick, R. F. (1990). Development of the trust in physician scale: A measure to assess interpersonal trust in patient-physician relationships. Psychological Reports, 67(3_suppl), 1091-1100.

Bachinger, S. M., Kolk, A. M., \& Smets, E. M. (2009). Patients' trust in their physicianPsychometric properties of the Dutch version of the "Wake Forest Physician Trust Scale". Patient Education and Counseling, 76(1), 126-131.

Balkrishnan, R., Dugan, E., Camacho, F. T., \& Hall, M. A. (2003). Trust and satisfaction with physicians, insurers, and the medical profession. Medical Care, 1058-1064.

Caterinicchio, R. P. (1979). Testing plausible path models of interpersonal trust in patient-physician treatment relationships. Social Science \& Medicine. Part A: Medical Psychology \& Medical Sociology, 13, 81-99.

Crawshaw, R., Rogers, D. E., Pellegrino, E. D., Bulger, R. J., Lundberg, G. D., Bristow, L. R., ... \& Barondess, J. A. (1995). Patient-physician covenant. Jama, 273(19), 1553-1553.

Elk, R., \& Landrine, H. (2012). Cancer disaparities: Causes and evidence-based solution. New York.: Springer Pub.

Epstein, R. M., Franks, P., Fiscella, K., Shields, C. G., Meldrum, S. C., Kravitz, R. L., \& Duberstein, P. R. (2005). Measuring patient-centered communication in patient-physician consultations: Theoretical and practical 1ssues. Social Science \& Medicine, 61(7), 1516-1528.

Fiscella, K., Meldrum, S., Franks, P., Shields, C. G., Duberstein, P., McDaniel, S. H., \& Epstein, R. M. (2004). Patient trust: Is it related to patient-centered behavior of primary care physicians?. Medical Care, 1049-1055.

Fuertes, J. N., Mislowack, A., Bennett, J., Paul, L., Gilbert, T. C., Fontan, G., \& Boylan, L. S. (2007). The physician-patient working alliance. Patient Education and Counseling, 66(1), 29-36.

Gezergün, A., Şahin, B., Tengilimoğlu, D., Demir, C., \& Bayer, E. (2006). Hastaların bakış açısıyla hekim-hasta ilişkisi ve iletişimi; bir eğitim hastanesi örneği, Sosyal Bilimler Dergisi, 1: 129-144.

Gulbrandsen, P., Lindstrøm, J. C., Finset, A., \& Hall, J. A. (2020). Patient affect, physician liking for the patient, physician behavior, and patient reported outcomes: A modeling approach. Patient Education and Counseling. 
Hair JF, Black WC, Babin BJ, Anderson, RE. (2014). Multivariate data analysis (Pearson new internat. ed). Harlow: Pearson.

Hall, M. A., Camacho, F., Dugan, E., \& Balkrishnan, R. (2002). Trust in the medical profession: conceptual and measurement issues. Health Services Research, 37(5), 1419-1439.

Hatcher L. (1994). A step-by-step approach to using the SAS system for factor analysis and structural equation modeling. Cary, NC: The SAS Institute.

Heybet, M., Tekin, O., Kahveci, R., Heybet, E. R., Yarloğlueş, G., Şencan, İ., ... \& Özkara, A. (2016). Hastalarda hekim algısına yönelik bir ölçek geliştirme çalışması: hekim ilişkili sağlık hizmeti algilama. Konuralp Tip Dergisi, 8 (2), 104-113.

Hillman, A. L. (1990). Health maintenance organizations, financial incentives, and physicians' judgments. Annals of Internal Medicine, 112(12), 891-893.

Hillman, A. L., Pauly, M. V., \& Kerstein, J. J. (1989). How do financial incentives affect physicians' clinical decisions and the financial performance of health maintenance organizations?. New England Journal of Medicine, 321(2), 86-92.

Huang, C. C., Wang, Y. M., Wu, T. W., \& Wang, P. A. (2013). An empirical analysis of the antecedents and performance consequences of using the moodle platform. International Journal of Information and Education Technology, 3(2), 217.

Kao, A. C., Green, D. C., Davis, N. A., Koplan, J. P., \& Cleary, P. D. (1998). Patients' trust in their physicians: Effects of choice, continuity, and payment method. Journal of General Internal Medicine, 13(10), 681-686.

Katz, J. (1984) The silent world of doctor and patient. New York: Free Press.

Kim, S. S., Kaplowitz, S., \& Johnston, M. V. (2004). The effects of physician empathy on patient satisfaction and compliance. Evaluation \& The Health Professions, 27(3), 237-251.

Lang, E. V (2012). A better patient experience through better communication. J Radiol Nur. 31, 114119.

Martin, K. D., Roter, D. L., Beach, M. C., Carson, K. A., \& Cooper, L. A. (2013). Physician Communication Behaviors and Trust Among Black and White Patients With Hypertension. Medical Care, 51(2), 151-157. doi:10.1097/mlr.0b013e31827632a2

Mechanic, D., \& Meyer, S. (2000). Concepts of trust among patients with serious illness. Social Science \& Medicine, 51(5), 657-668.

Mechanic, D., \& Schlesinger, M. (1996). The impact of managed care on patients' trust in medical care and their physicians. Jama, 275(21), 1693-1697.

Nie, J. B., Tucker, J. D., Zhu, W., Cheng, Y., Wong, B., \& Kleinman, A. M. (2017). Rebuilding patientphysician trust in China, developing a trust-oriented bioethics. Developing World Bioethics.

Parchman, M. L., \& Burge, S. K. (2004). The patient-physician relationship, primary care attributes, and preventive services. Family Medicıne-Kansas City, 36(1), 22-27.

Pellegrini, C. A. (2017). Trust: the keystone of the patient-physician relationship. Journal of the American College of Surgeons, 224(2), 95-102.

Peng, Y., Yin, P., Deng, Z., \& Wang, R. (2020). Patient-Physician Interaction and Trust in Online Health Community: The Role of Perceived Usefulness of Health Information and Services. International Journal of Environmental Research and Public Health, 17(1), 139. 
Rolfe, A., Cash-Gibson, L., Car, J., Sheikh, A., \& McKinstry, B. (2014). Interventions for improving patients' trust in doctors and groups of doctors. Cochrane Database of Systematic Reviews, (3).

Sackett, D. L., Rosenberg, W. M., Gray, J. M., Haynes, R. B., \& Richardson, W. S. (1996). Evidence Based Medicine: What it is and what it isn't. Clin Orthop Relat Res, 455, 3-5.

Sherwood, A., Brinkmann, J., \& Fatone, S. (2018). Review of benefits to practitioners of using good patient-practitioner communication. JPO: Journal of Prosthetics and Orthotics, 30 (1), 5-12.

Song, H., Zuo, X., Cui, C., \& Meng, K. (2019). The willingness of patients to make the first visit to primary care institutions and its influencing factors in Beijing medical alliances: a comparative study of Beijing's medical resource-rich and scarce regions. BMC Health Services Research, 19(1), 361.

Sulmasy, D. P. (1992). Physicians, cost control, and ethics. Annals of Internal Medicine, 116(11), 920926.

Thom, D. H. (2001). Physician behaviors that predict patient trust. Journal of Family Practice, 50(4), 323-323.

Thom, D. H., \& Campbell, B. (1997). Patient-Physician Trust: An Exploratory Study. The Journal of Family Practice, 44(2), 169.

Thom, D. H., Kravitz, R. L., Bell, R. A., Krupat, E., \& Azari, R. (2002). Patient trust in the physician: relationship to patient requests. Family Practice, 19(5), 476-483.

Thom, D. H., Ribisl, K. M., Stewart, A. L., Luke, D. A., \& The Stanford Trust Study Physicians. (1999). Further validation and reliability testing of the Trust in Physician Scale. Medical Care, 510-517.

Thom, D. H., Wong, S. T., Guzman, D., Wu, A., Penko, J., Miaskowski, C., \& Kushel, M. (2011). Physician trust in the patient: development and validation of a new measure. The Annals of Family Medicine, 9(2), 148-154.

Thom, H. D. (2000). Training physicians to increase patient trust. Journal of Evaluation in Clinical Practice, 6(3), 245-253.

Trachtenberg, F., Dugan, E., \& Hall, M. A. (2005). How patients' trust relates to their involvement in medical care. Journal of Family Practice, 54(4), 344-354.

Urfa, O., Yıldızer, G., Aşçı, F. H., Çağlar, E., \& Miçooğulları, B. O. (2019). Kendini Fiziksel Tanımlama Envanteri Kısa Formunun Ergenlerde Geçerlilik ve Güvenirliliği. Turkiye Klinikleri Spor Bilimleri, 11(3): 153-63.

Weng, H. C. (2008). Does the physician's emotional intelligence matter?: Impacts of the physician's emotional intelligence on the trust, patient-physician relationship, and satisfaction. Health Care Management Review, 33(4), 280-288.

Whitcomb, M. E (2000). Communication and professionalism. Patient Educ Couns, 41, 137-144.

Yıldız, M. A. (2016). Ergenler için öfke düzenleme ölçeğinin (Eİ̈DÖ) geliştirilmesi ve psikometrik özelliklerinin incelenmesi. Düşünen Adam. The Journal of Psychiatry and Neurological Sciences, 29:247-258.

Yılmaz, A. A. (2005). Hasta-Hekim İlişkisinde Güven İletişimi Akdeniz Üniversitesi Tıp Fakültesi Kadın Hastalıkları ve Doğum Anabilim Dalı Tüp Bebek Ünitesinde bir Uygulama. (Yayınlanmış Yüksek Lisans Tezi). Akdeniz Üniversitesi, Sosyal Bilimler Enstitüsü, Antalya. 